Biografistyka Pedagogiczna

Rok 3 (2018) nr 1

ISSN 2543-6112; e-ISSN 2543-7399

DOI: 10.36578/BP.2018.03.16

Anna Marta Żukowska*

\title{
Edukacja plastyczna i wychowanie estetyczne w średnim szkolnictwie ogólnokształcącym na Lubelszczyźnie w okresie międzywojennym
}

\author{
Artistic and Aesthetic Education in General Secondary \\ Schools in the Lublin Region During the Interwar Period
}

\begin{abstract}
Drawing lessons were the foundation of artistic education and at the same time a form of aesthetic education for students attending general secondary schools in interwar Poland. Drawing as a school subject played a prominent role in educating young people, both due to its practical applications and educational value, enriching one's personality and sensitizing one to the aesthetics of everyday life. The subject was included in general secondary school curricula both after Poland regained independence in 1918 and in the wake of the Jędrzejewicz reform in 1932. Artistic and aesthetic education was pursued in all types of general schools in the Lublin region. Surviving archival materials (curricula, school authority reports, artworks from 1918-1939, etc.) haves allowed the author to reconstruct the place and role of drawing in secondary education in the Lublin region.
\end{abstract}

Keywords: artistic education, Poland 1919-1939, aesthetic education, secondary school

* Anna Marta Żukowska - dr hab., prof. Uniwersytetu Marii Curie-Skłodowskiej w Lublinie, anmartzuk@interia.pl. 
W latach międzywojennych podstawą edukacji plastycznej i zarazem jedną z form wychowania estetycznego uczniów szkół średnich była nauka rysunku. Rysunek jako szkolny przedmiot nauczania odgrywał doniosłą rolę w wykształceniu i wychowaniu młodzieży zarówno ze względu na jego praktyczne zastosowanie w życiu, jak i walory wychowawcze przyczyniające się do ubogacania osobowości i estetyki dnia codziennego. Pod koniec lat trzydziestych, kiedy zaczęła zarysowywać się obawa przed wojną, odgrywał ważną rolę w wychowaniu i przysposobieniu obronnym uczniów. Cele, jakie wyznaczono nauce rysunku, znalazły odbicie w szkolnych programach nauczania.

\section{Założenia programowe edukacji plastycznej}

W 1918 r. programy, na których opierały swoją działalność dydaktyczno-wychowawczą szkoły średnie nie były ujednolicone. Odzyskanie niepodległości przyniosło szkołom ważne zmiany. Gimnazja szukały pod względem programu nauczania i wychowania zgodności z rozporządzeniami centralnych władz szkolnych.

Zgodnie z wydanym w 1919 r. przez Ministerstwo Wyznań Religijnych i Oświecenia Publicznego Programem naukowym szkoły średniej, ośmioletnie gimnazja podzielono na dwa szczeble programowe: 3-letni niższy, tzw. przygotowawczy i 5-letni wyższy - systematyczny oraz na cztery zasadnicze typy: humanistyczny, matematyczno-przyrodniczy, humanistyczny z językiem łacińskim i klasyczny ${ }^{1}$. Znaczna część szkół średnich Lubelszczyzny zdecydowała się na realizację programu humanistycznego lub humanistycznego z łaciną. W początkowych latach dwudziestolecia, obok 33-35 szkół humanistycznych istniało w województwie: 6 gimnazjów matematyczno-przyrodniczych i 4 mieszane ${ }^{2}$.

Zarówno w klasach I-III gimnazjum niższego, jak i wszystkich typach gimnazjum wyższego program nauczania uwzględniał „rysunki” w stosunkowo dużej liczbie godzin: w klasie I - 4 godziny tyg., w klasach II-VI po 2 godziny tyg., z wyjątkiem klasy vi na kierunku klasycznym, w której na naukę rysunku

1 Program naukowy szkoły średniej. Projekt wypracowany przez Sekcję Szkolnictwa Średniego, Warszawa 1919.

2 B. Wierzchowska-Konera, Szkolnictwo średnie ogólnokształcące w województwie lubelskim w latach 1918-1939, Lublin 1981, rozprawa doktorska napisana pod kierunkiem prof. dra hab. K. Poznańskiego, maszynopis, UMCS - Archiwum, s. 290. 
przeznaczono tylko 1 godzinę tyg. W klasach VII-VIII rysunek był przedmiotem nadobowiązkowym ${ }^{3}$. Wymienionej ilości godzin, która wydaje się dziś bardzo duża, nie uważano bynajmniej za nadmierną, skoro, biorąc pod uwagę ewentualną redukcję zajęć, w programie nauczania zastrzegano, iż „trudno myśleć o zmniejszeniu tak skromnej ilości lekcji rysunków lub gimnastyki”"4.

Zamieszczony w planie godzin szkolnych materiał nauczania podano w formie haseł bardzo krótko i identycznie dla wszystkich typów gimnazjów. W kl. I przewidywano martwą naturę płaską i modelowanie; w kl. II - głównie łatwe bryły i kontynuację modelowania; w kl. III - martwą naturę rysowaną i malowaną; w dwóch następnych klasach IV i v - przedmioty o powierzchniach krzywych i złożonych; w kl. vI, ostatniej, zalecano rysunek głowy i figury ludzkiej. Podkreślano też, „by tendencja, której przejawem jest wprowadzenie [...] wycieczek przyrodniczych znalazła miejsce również w nauczaniu takich przedmiotów jak rysunki i prace ręczne" ${ }^{\prime 5}$.

Kolejny program nauczania rysunku dla gimnazjum państwowego, bardziej dopracowany i uszczegółowiony, został wprowadzony do szkół Lubelszczyzny po 1922 r. Cele nauczania przedmiotu ujęto następująco:

- rozwijać spostrzegawczość, pamięć i wyobraźnię w zakresie kształtów i barw; wyrabiać dokładność spostrzeżeń i wyobrażeń plastycznych oraz umiejętność ich syntetyzowania;

- kształcić umiejętność wyrażania tych spostrzeżeń i wyobrażeń za pomocą środków plastycznych, a w związku z tym stymulować rozwój twórczy;

- wyrabiać poczucie i umiłowanie piękna kształtów i barw w naturze i dziełach sztuki ${ }^{6}$.

We wszystkich klasach na rysunek przeznaczono po 2 godziny tygodniowo, co wydawało się być wystarczające na zrealizowanie treści programowych w poszczególnych klasach. Należy zauważyć, iż programy gimnazjum niższego były identyczne z programem wyższych klas szkoły powszechnej. I tak, program rysunku klasy I gimnazjum odpowiadał programowi klasy v szkoły

3 Program naukowy szkoły średniej, tabl. I, II, III, IV.

4 Tamże, s. III.

5 Tamże, s. 99.

6 Program Gimnazjum Państwowego. Wydział matematyczno-przyrodniczy, Warszawa 1922, s. IV. 
powszechnej ${ }^{7}$. Zakładał on dokładną realizację ćwiczeń w rysowaniu z pokazu i modela. Podstawą ćwiczeń miało być malowanie tzw. sylwetowe wybranych kształtów, szybkie szkicowanie elementów płaskich, wycinanie z papieru form roślinnych o czytelnych i zdecydowanych kształtach. W klasie II program gimnazjum - analogicznie do programu klasy VI szkoły powszechnej - poszerzony został o „rysunek przestrzenny z natury z zastosowaniem praw perspektywy” wyrażony konturem i światłocieniem ${ }^{8}$. W klasie III zalecano rysowanie i malowanie przedmiotów codziennego użytku, o powierzchniach płaskich i krzywych z uwzględnieniem charakterystycznych sprzętów i naczyń ludowych. Kontynuowane były szkice przedmiotów w perspektywie i ćwiczenia kompozycyjne o wyższym progu wymagań ${ }^{9}$. W klasach starszych gimnazjum zwracano szczególną uwagę na ćwiczenia dekoracyjne, rysowanie i malowanie z pamięci i wyobraźni, wykonywanie rysunków studyjnych z natury: zwierząt, głowy ludzkiej i postaci w ruchu, a także oglądanie dzieł sztuki ${ }^{10}$.

W wyniku tzw. reformy jędrzejewiczowskiej nastąpiła przebudowa struktury szkolnictwa, a wraz z nią w marcu 1932 r. ogłoszono nową ustawę zmieniającą program szkół średnich. W miejsce dawnego 8-letniego gimnazjum ogólnokształcącego wprowadzono 6-letnią szkołę średnią ogólnokształcącą podzieloną na 4-letnie gimnazjum jednolite pod względem programowym i 2-letnie liceum programowo zróżnicowane na wydziały: klasyczny, humanistyczny, matematyczno-fizyczny i przyrodniczy, których podstawę dydaktyczną stanowiły odpowiednio dobrane grupy przedmiotów. W programie nauki w państwowym gimnazjum ogólnokształcącym, wydanym w 1934 r., wysuwano jako cel pracy szkolnej „wychowanie i kształcenie młodzieży na świadomych swych obowiązków, twórczych obywateli Rzeczypospolitej”. Zalecano, aby „wszystkie dziedziny pracy szkoły jednoczyły się w wytwarzaniu u młodzieży czynnego i możliwie twórczego stosunku do państwa"11. Wydany trzy lata później (1937) Program nauki w państwowym liceum ogólnokształcącym, jako główne zadania

7 Projekt. Program nauki w siedmioklasowych publicznych szkołach powszechnych i w trzech niższych klasach gimnazjum państwowego. Rysunek, Warszawa 1929, s. 3-6.

8 Tamże.

9 Tamże.

10 Tamże, s. 117-118.

11 Historia wychowania wiek XX, red. J. Miąso, Warszawa 1984, s. 68. 
tej szkoły wysuwał przygotowanie młodzieży do studiów wyższych i samodzielnej pracy nad sobą oraz udzielenie jej pomocy w wyrabianiu poglądu na świat, porządkowaniu własnych myśli i indywidualnych przeżyć. Położono przy tym akcent na zespolenie wiadomości zdobytych w szkole średniej w jedną zwartą całość np.: wyrabianie umiejętności posługiwania się zdobytą wiedzą, przyzwyczajanie do logicznego myślenia i jasnego formułowania poglądów. Równocześnie podkreślano potrzebę pogłębienia intelektualnego i emocjonalnego związku wychowanków z kulturą narodową ${ }^{12}$.

W obu typach szkół uwzględniono naukę rysunku, przy czym we wszystkich czterech klasach gimnazjum, a także w liceum na kierunku humanistycznym i klasycznym występował on jako przedmiot nadobowiązkowy w wymiarze 2 godz. tygodniowo. Większą rangę przedmiot zyskał w licealnych profilach: matematyczno-fizycznym i przyrodniczym, gdzie realizowany był jako obowiązkowy w wymiarze 2 godzin tygodniowo ${ }^{13}$.

Celem nauki rysunku w 4-letnim gimnazjum było pogłębienie sprawności rysunkowych nabytych w szkole powszechnej, rozwijanie i doskonalenie technik plastycznych oraz ćwiczenia w wyrażaniu linią i plamą barwną kształtu przedmiotów i zjawisk świata zewnętrznego. Podkreślano potrzebę kształcenia estetycznego ${ }^{14}$, w tym uwrażliwiania na rodzimą sztukę polską ze szczególnym akcentem na jej cechy charakterystyczne, znaczenie i rolę w życiu społecznym, a także sukcesy sztuki polskiej za granicą ${ }^{15}$.

Edukacja rysunkowa w nowo utworzonym liceum ogólnokształcącym opierała się na podstawach, jakie uczniowie wynieśli ze szkoły powszechnej lub gimnazjum. Kierunek nauki wytyczał Program nauki w państwowym liceum ogólnokształcacym z polskim językiem nauczania wydany przez MWRioP. W konstrukcji programu przewidziano zróżnicowany poziom umiejętności rysunkowych młodzieży. Łatwiejszy materiał nauczania przeznaczony dla uczniów słabiej przygotowanych zgrupowany był w wariancie A, wariant B przeznaczony był dla uczniów zdolniejszych plastycznie i bardziej zaawansowanych

12 Tamże, s. 69.

13 Program nauki $w$ państwowym liceum ogólnokształcacym $z$ polskim językiem nauczania. Tymczasowy. Rysunki, Warszawa 1937.

14 Program nauki $w$ gimnazjach państwowych $z$ polskim językiem nauczania, Warszawa 1934.

15 Tamże, s. 360 . 
w nauce. Celem edukacji rysunkowej było dążenie do pogłębiania umiejętności wyrażania środkami plastycznymi prostych kształtów i barw z natury i wyobraźni, a także komponowanie plastyczne. Oprócz umiejętności praktycznych zakładano rozwijanie spostrzegawczości, pamięci wzrokowej oraz zdolności twórczych uczniów. Duży nacisk kładziono na pogłębianie kultury plastycznej młodzieży, budzenie szacunku dla sztuki i jej zabytków, uzmysławianie roli i znaczenia sztuki w kulturze narodu. To z kolei co prowadzić miało do poglądowego orientowania uczniów w najważniejszych okresach sztuki polskiej i obcej ${ }^{16}$.

Na uwagę zasługują formalne zalety programów szkolnych: znakomicie opracowane uwagi metodyczne, dobór treści podporządkowany idei naczelnej, szerokie uwzględnienie zasady korelacji treści nauczania poszczególnych przedmiotów, elastyczność programów pobudzająca inicjatywę nauczyciela i pozwalająca na uwzględnienie elementów regionalnych i środowiskowych w nauczaniu ${ }^{17}$.

Założenia programowe towarzyszące nowym ustawom nauczycielskie środowisko Lubelszczyzny przyjęło bez większego entuzjazmu, jakkolwiek w dużej mierze spełniały one postulaty głoszone przed $1932 \mathrm{r}$. Realizowały one między innymi tezę mówiącą o potrzebie korelacji międzyprzedmiotowej, o stworzeniu z nauki języka polskiego osi nauczania w szkole średniej i zwróceniu szczególnej uwagi na znajomość kultury polskiej i na zagadnienia realizmu.

\section{Pomoce naukowe}

Czasopisma pedagogiczne ukazujące się w latach międzywojennych dość często zamieszczały spis pomocy naukowych i przyborów niezbędnych do nauczania rysunku w szkołach ogólnokształcących. Do podstawowych sprzętów i materiałów stanowiących własność szkoły zaliczano: dużą tablicę oraz jasne linoleum do rysowania, bloki, paletki metalowe, pojemniki do rozrabiania farb, dwustronne pędzle, komplety kolorowej kredy, komplety nożyczek, glinę odpowiednio wyrobioną, kawałki linoleum i miednice do mycia rąk ${ }^{18}$. Jako niezbędne modele służące edukacji rysunkowej w gimnazjach wymieniano: barwne pióra,

16 Program nauki (tymczasowy) w państwowym gimnazjum ogólnokształcącym z polskim językiem nauczania . Rysunek, Warszawa 1937, s. 3.

17 Historia wychowania, s. 70.

18 A. Martynowiczówna, Rysunek w szkole powszechnej, „Sprawy Szkolne”, 7 (1931) s. $20-22$. 
liście, przedmioty domowego użytku z drewna, szkła i gliny, okazy ceramiki ludowej, ruchome kwadraty i koła do ćwiczeń perspektywicznych, bryły geometryczne, a także modele figuralne i odlewy głowy ludzkiej oraz eksponaty sztuki ludowej i narodowej. Natomiast ekwipunek plastyczny ucznia stanowić miały: zeszyty z brystolu, kredki w papierkach, minimum trzy zasadnicze farby w dobrym gatunku lub komplet farb w metalowym pudełeczku, szary papier, bibuła kolorowa i miękki ołówek ${ }^{19}$. Skompletowanie przez ucznia takiego zestawu nie zawsze było możliwe, głównie ze względów finansowych, o czym informował jeden z nauczycieli lubelskich gimnazjów na łamach dwumiesięcznika „Roboty Ręczne i Rysunki” ${ }^{20}$ : „daremne były wszelkie próby nauczyciela w kierunku, by dzieci same sobie materiały kupiły"21.

W pierwszych latach okresu międzywojennego szkoły średnie Lubelszczyzny korzystały głównie z pomocy naukowych przejętych w spadku po zakładach, których działalność kontynuowały, bądź z pomocy dydaktycznych zrobionych własnoręcznie przez uczniów i nauczycieli. Ich stan zarówno ilościowy, jak i jakościowy był niewystarczający. Oto np. inwentarz środków dydaktycznych do nauki rysunków w Państwowym Gimnazjum Męskim w Krasnymstawie w 1918 r. liczył zaledwie 7 pozycji ${ }^{22}$, W gimnazjum matematyczno-przyrodniczym w Łukowie cały inwentarz szkolnych pomocy wynosił 302 pozycje, z czego tylko 13 przeznaczono do nauki rysunku ${ }^{23}$. Gimnazjum koedukacyjne w Tomaszowie Lubelskim w 1920 r. posiadało jedynie przykłady wzorów rysunkowych. ${ }^{24}$ Natomiast gimnazjum im. Stanisława Staszica w Lublinie dysponowało tylko

19 Tamże, s. 20, 22.

20 W 1929 r. czasopismo „Roboty Ręczne” poszerzyło swój zakres tematyczny o problematykę rysunku i zmieniło nazwę na „Roboty Ręczne i Rysunki”. Redaktorem czasopisma był Wiktor Snopek, a wydawcą Sekcja Nauczycieli Robót Ręcznych i Rysunków Związku Polskiego Nauczycielstwa Szkół Powszechnych (ZPNSP). Analiza czasopisma wykazała, iż wielu nauczycieli lubelskich szkół dzieliło się swoimi doświadczeniami na jego łamach.

21 Premisa, Dążenia, programy, a rzeczywistość w nauce rysunku, „Roboty Ręczne i Rysunki", 1930, nr 1, s. 24.

22 Sprawozdanie Dyrekcji Państwowego Gimnazjum Męskiego w Krasnymstawie za rok 1918/19, Krasnystaw 1919.

23 B. Wierzchowska-Konera, Szkolnictwo średnie, s. 125, 132.

24 Sprawozdanie Dyrekcji Państwowego Gimnazjum Koedukacyjnego w Tomaszowie Lubelskim za rok 1918/19, Tomaszów Lubelski 1919. 
14 egzemplarzami gromadzonymi w szafach ulokowanych w korytarzu szkolnym $^{25}$. Wartym odnotowania jest fakt, iż biblioteka szkolna w swoich zbiorach posiadała czasopisma wspomagające naukę rysunku: miesięcznik „Rysunki i Zajęcia Praktyczne” oraz „Sztuki Piękne”.

W szkołach średnich zdecydowanie eliminujących werbalne metody nauczania, niekiedy już w początkowym okresie działalności, w miarę możliwości finansowych organizowano gabinety i pracownie rysunkowe zwane niekiedy salami rysunkowymi. Wprowadzenie do szkół w roku szkolnym 1919/1920 nowych programów nauczania wymagało szybkiego uzupełnienia zestawów pomocy naukowych. Było to wyzwanie dość trudne, gdyż wysokie ceny oraz braki w handlu nie pozwalały w należytym stopniu na zaopatrzenie szkół w środki dydaktyczne do nauki rysunku. Pierwsze potrzeby inwestycyjne szły raczej w kierunku uzupełnienia najniezbędniejszych do funkcjonowania zakładów sprzętów, takich jak ławki, szafy, tablice. Mimo to gimnazja w niewielkim stopniu dokonywały zakupu pomocy do nauki rysunku: Gimnazjum Państwowe im. Hetmana Jana Zamojskiego w Lublinie od momentu przejęcia w 1922 r. nowego budynku przy ulicy Ogrodowej dysponowało odpowiednio wyposażonymi salami dla każdego przedmiotu. Sale były widne i przestronne, zaopatrzone w potrzebne środki dydaktyczne ${ }^{26}$. Gimnazjum w Białej Podlaskiej w 1922 r. zakupiło 46 „nowych obrazów"27. Podobnie Gimnazjum Koedukacyjne Wydziału Powiatowego Sejmiku Janowskiego w Kraśniku w latach trzydziestych „znaczną kwotę pieniędzy przeznaczyło m.in. na roboty ręczne i rysunki”28. Spośród lubelskich szkół prywatnych do najbardziej zasobnych w pomoce naukowe należały: Prywatne Męskie Gimnazjum im. Stefana Batorego, zwane „Szkołą Lubelską”, będące po pierwszej wojnie światowej największą szkołą średnią w Lublinie, w której w roku szkolnym 1934/1935 w pracowni zajęć praktycznych i rysunku zgromadzono sprzęt i pomoce naukowe na kwotę 1684,43 zł, następnie - Prywatne

25 Sprawozdanie Dyrekcji gimnazjum Państwowego im. Stanisława Staszica w Lublinie za rok 1934/1935, Lublin 1935.

26 A. Woch, Szkolnictwo średnie ogólnoksztatcace Lublina w latach 1918-1939, Lublin 2013, s. 68.

27 I Sprawozdanie 3-letniego Państwowego Gimnazjum im. E. Plater w Białej Podlaskiej za lata 1919/1920, 1920/1921, 1922/1923, Biała Podlaska 1923.

28 Archiwum Szkolne Liceum Ogólnokształcącego w Kraśniku, Protokoły z posiedzenia Rady Pedagogiczne z dn. 31 sierpnia $1938 \mathrm{r}$. 
Żeńskie Gimnazjum Wacławy Arciszowej, które po przeniesieniu do większego budynku przy ul. Radziwiłłowskiej zyskało nowe pomieszczenia, w tym również pracownię rysunku mieszczącą dużą ilość plastycznych eksponatów, a także Gimnazjum Żeńskie Sióstr Urszulanek. Placówką dobrze wyposażoną w sprzęt dydaktyczny było II Liceum i Gimnazjum Żeńskie im. Królowej Jadwigi w Chełmie uruchomione w 1933/1934 roku szkolnym, kiedy to, realizując założenia szkolnej reformy „jędrzejewiczowskiej”, przyjęto pierwsze uczennice gimnazjalne. W 1938 r. szkoła otrzymała aparat filmowy celem wyświetlania dla młodzieży filmów z zakresu kultury, zajęć praktycznych oraz biologii, fizyki i geografii. Opiekę nad aparatem sprawowała Władysława Mrożkiewiczowa, która po odbyciu specjalnego kursu w Warszawie zapoznała grono nauczycielskie z działaniem i instrukcją obsługi aparatu ${ }^{29}$. Pomocami do nauki rysunku dysponowały też: gimnazja biskupie w Lublinie i Siedlcach ${ }^{30}$ oraz Gimnazjum Humanistyczne im. Henryka Sienkiewicza w Sokołowie Podlaskim ${ }^{31}$.

Mimo poważnych trudności finansowych w gimnazjach zakładano pracownie rysunkowe. Pracownię rysunkową utworzono w Państwowym Gimnazjum im. Stefana Czarnieckiego w Chełmie. Jej wyposażenie stanowiły m.in. modele gipsowe i zbiory reprodukcji dzieł malarskich twórców polskich i zagranicznych ${ }^{32}$. Dużą ilość pracowni, bo aż dziesięć, utworzono w Gimnazjum Żeńskim w Puławach, w tym również pracownię do nauki rysunku ${ }^{33}$. Warto też wspomnieć, iż dobrze wyposażoną pracownię rysunkową posiadało Seminarium Nauczycielskie Żeńskie w Chełmie, będące pierwszą w Polsce szkołą, w której prowadzono naukę - w tym również rysunku i prac ręcznych - systemem daltońskim. Była to udana próba unowocześnienia procesu dydaktyczno-wychowawczego, podjęta z inicjatywy Jadwigi Młodowskiej, która znała braki naszych metod nauczania i wychowania ${ }^{34}$.

29 P. Kiernikowski, Miasto Chełm w okresie międzywojennym (1918-1939), Chełm 2007, S. 197.

30 B. Wierzchowska-Konera, Szkolnictwo średnie, s. 132.

31 Tamże, s. 134.

32 P. Kiernikowski, Miasto Chetm w okresie międzywojennym (1918-1939), s. 191.

33 Sprawozdanie Gimnazjum Żeńskiego w Puławach za rok 1932/1933, Puławy 1934.

34 Dr Jadwiga Młodowska (Wychowawczyni i pracownica społeczna), zebrała i ułożyła B. Bobrowska, Kraków 1935, s. 38. 
Dużym wsparciem w nauczaniu rysunku w gimnazjach były szkolne muzea gromadzące w swoich zbiorach różne eksponaty z zakresu sztuki. Przy gimnazjum chełmskim istniało muzeum, którego zbiory w 1934 r. obejmowały 9 działów. Najliczniej reprezentowany był dział sztuki kościelnej i cerkiewnej. Znajdowały się tu miedzy innymi figurki z kapliczek przydrożnych, portrety biskupów chełmskich, płyta nagrobna poświęcona pamięci biskupa Ferdynanda Dąbrowy-Ciechanowskiego oraz zabytkowa księga biskupa Jakuba Suszy wydana w 1684 r. Była to historia o Chełmie i chełmskiej ziemi ${ }^{35}$. W Gimnazjum Męskim im. Hetmana Jana Zamojskiego w Zamościu dwa spośród siedmiu usystematyzowanych działów muzeum szkolnego poświęcone były ceramice ludowej i rycinom ${ }^{36}$. Trzecie w województwie lubelskim muzeum szkolne przy Gimnazjum im. Hetmana Żółkiewskiego w Siedlcach posiadało bogatą kolekcję strojów ludowych ${ }^{37}$. Muzeum szkolne przy Gimnazjum im. Józefa Ignacego Kraszewskiego w Białej Podlaskiej gromadziło eksponaty związane ze sztuką ludową - zbiór pisanek i strojów z okolic Podlasia ${ }^{38}$.

Zbiory bibliotek szkolnych różnie przedstawiały się w poszczególnych gimnazjach. Ogólnie można stwierdzić, że w większości wypadków z dziedziny sztuk pięknych nie dysponowano prawie żadnymi pozycjami, a z czasopism specjalistycznych można było spotkać miesięczniki: „Rysunek i Zajęcia Praktyczne” oraz „Sztuki Piękne” poświęcone architekturze, rzeźbie, malarstwu, grafice i zdobnictwu.

\section{Metody i formy nauczania}

W pierwszym dziesięcioleciu okresu międzywojennego w szkołach średnich Lubelszczyzny - podobnie jak w większości szkół w kraju - powszechnie stosowanymi metodami dydaktycznymi były metody tradycyjne. W odniesieniu

35 K. Janczykowski, O wyzyskanie Muzeum Regionalnego Ziemi Chełmskiej dla potrzeb szkolnych w zwiazku z nowymi programami, „Dziennik Urzędowy KOsL”, 1934, nr 2, s. 84 .

36 B. Wierzchowska-Konera, Szkolnictwo średnie, s. 135.

37 J. Mikulski, Muzeum w Siedlcach, „Dziennik Urzędowy KosL”, 1934, nr 2, s. 91-93.

38 Archiwum L. K., Księga Protokołów Naczelnej Organizacji Młodzieży na terenie Państwowego Gimnazjum im. J. I. Kraszewskiego w Białej Podlaskiej, rok szk. 1938/39. 
do edukacji plastycznej, tradycjonalizm metodyczny przejawiał się między innymi w egzekwowaniu przez nauczyciela prac rysunkowych uczniów wykonanych sposobem kopiowania wzorów uznanych za „estetycznie doskonałe" ${ }^{39}$.

Bardzo często pedagogika i publicystyka pedagogiczna rozważały stosowanie heurezy, co nie pozostawało bez wpływu na edukację rysunkową. Nauczyciel jednego z lubelskich gimnazjów, dzieląc się swoimi doświadczeniami na łamach „Dziennika Urzędowego Kuratorium Okręgu Szkolnego Lubelskiego”, pisał, iż często w pracy z młodzieżą stosuje korektę mającą na celu doprowadzenie ucznia metodą heurystyczną do poprawienia lub przerobienia własnego rysunku, prowokuje też tzw. autokorektę, gdzie uczeń porównując własną pracę z modelem wyszukuje i poprawia popełnione błędy ${ }^{40}$.

W gimnazjach lubelskich sporo miejsca poświęcano ćwiczeniom zdobniczym, widząc ich przydatność w życiu codziennym. Motyw zdobniczy opracowywano głównie w oparciu o naturę, po czym wykorzystywano go w kompozycjach ornamentacyjnych, stosując najczęściej technikę akwarelową. Ten typ ćwiczeń szczególnie popularny był w Państwowym Gimnazjum Żeńskim im. Unii Lubelskiej. Na podstawie analizy prac plastycznych wykonanych w latach 1925-1930 w tejże szkole udało się ustalić szczegółowe tematy lekcji: „Kompozycja na tkaninę, Projekt wzoru haftu na poduszkę, Kompozycja ozdobna na piórnik, Projekt ozdobnej ramki na zdjęcia, Ornament dekoracyjny pasowy i Kompozycja symetryczna wieloosiowa w kole"41. Nauczyciele będący absolwentami szkół krakowskich przenosili zamiłowanie do ornamentu i zdobnictwa na grunt szkoły, w której pracowali. Jan Franciszek Świeży, nauczyciel Gimnazjum im. Władysława Jagiełły w Krasnymstawie, z zamiłowania etnograf, naukę rysunku opierał na ćwiczeniach zdobniczych. Indywidualna i dość oryginalna metoda nauki ornamentu wypracowana przez nauczyciela tej szkoły polegała na doborze i zachowaniu kolejności następującej kategorii ćwiczeń:

39 A. M.Żukowska, Koncepcje edukacji plastycznej i metody ich realizacji w polskiej pedagogice artystycznej, w: Komunikowanie artystyczne, red. M. Stępnik, Lublin 2011, s. 99.

40 J. Firewicz, Uwagi o stosowaniu rysunku w nauczaniu przyrodoznawstwa „Dziennik Urzędowy KOSL", 1928, nr 3, s. 21.

41 Prace plastyczne uczennic: K. Wolińskiej kl. II z 1930 r.; A. Korniejew kl. v; M. Kochmanówny, H. Menchówny kl. III; M. Krzyśniakówny, I. Frydrychas kl. iI z 1929 r. w zbiorach prywatnych autorki. 
1) praca nad poznawaniem i wczuwaniem się ucznia w treść i właściwości fizyczno-chemiczne barw zasadniczych;

2) komponowanie różnorodnych motywów dekoracyjnych i kolorystycznych na podstawie doświadczeń nabytych w zakresie barwy;

3) zdobienie przez uczniów płaskich form nawiązujących do form otaczających ich przedmiotów - wykorzystanie zdobytej wiedzy i zdolności artystycznych uczniów w celach praktyczno-użytkowych;

4) ćwiczenia wolnoręczne (swobodne) inspirowane „naturą żywą” głównie krajobrazem otaczającym młodzież (rząd wierzb, szmat przeoranej ziemi itp.) ${ }^{42}$.

Uczniowie pracujący tą metodą osiągali interesujące rezultaty, czego dowodem były prace prezentowane na wielu wystawach w Lublinie ${ }^{43}$. Nauczanie kompozycji zdobniczej kierowało twórczość uczniów ku praktyce, przybliżało też zagadnienie rodzimego przemysłu artystycznego .

Potrzeba poznania najbliższego środowiska i jego charakterystycznych cech, „konieczność związania młodzieży więzami uczuciowymi i naukowymi z najbliższym regionem" to idee rzucone oficjalnie w związku z reformą szkolną w 1932 r., które natrafiały niekiedy na wcześniej przygotowany grunt. Już w 1918 r. nauczyciel koedukacyjnej szkoły średniej w Urzędowie wielokrotnie organizował wycieczki do pobliskiego Bęczyna w celu obejrzenia zabytkowych pieców i poznania procesu wypalania wyrobów garncarskich i drobnych figurek z gliny ${ }^{44}$.

Analiza archiwalnych prac plastycznych uczniów, głównie rysunkowych pochodzących z lat 1918-1939, pozwala wysnuć wniosek, iż w szkołach lubelskich zajęcia w plenerze stanowiły popularną formą dydaktyczną. Ich celem była obserwacja zjawisk przestrzennych, perspektywicznych i formalnych koniecznych do wykonania szkiców rysunkowych. Motywem rysunkowym w przeważającej części była lubelska architektura: kościoły, kamienice i nastrojowe uliczki starego miasta, ale też pomniki i okoliczne kapliczki.

Odpowiednie wykorzystywanie wiadomości środowiskowych miało zgodnie z zaleceniami programowymi „wzniecić w młodzieży silniejsze umiłowanie Polski”. W sprawozdaniach dyrekcji szkół miejskich z lat międzywojennych często poja-

42 Referat prof. J. Świeżego, „Kształt i Barwa”, 3 (1923) s. 9.

43 J. Kot, Swojski ornament w szkole średniej, „Kształt i Barwa”, 3 (1923) s. 7-8.

44 Była to niżej zorganizowana 4-klasowa koedukacyjna szkoła średnia utrzymywana przez Spółkę Cywilną Obywateli Ziemskich w Urzędowie. 
wiają się informacje, że młodzież w ramach edukacji rysunkowej i wychowania estetycznego zwiedzała miasto „obfitujące” w pomniki architektury lub uczestniczyła w lekcjach odbywających się w muzeach. Nauczyciele szkół usytuowanych w mniejszych miejscowościach w ramach rysunku zapoznawali uczniów z najbliższą okolicą i jej specyfiką rzemieślniczo-artystyczną przejawiającą się często w wytwórczości garncarskiej - czego przykładem jest wyżej wspomniany już Bęczyn - wikliniarskiej, tkackiej, kowalskiej (Wojciechów), a także twórczości ludowej takiej jak: rzeźba ludowa, malarstwo na szkle, hafciarstwo, pisankarstwo.

Nauczyciele realizujący w praktyce szkolnej hasła "regionalizmu” wielokrotnie posługiwali się wycieczką, jako nowatorską formą dydaktyczną. Była ona wykorzystywana głównie podczas zajęć odnoszących się do wychowania estetycznego. Jej celem było zwiedzanie muzeów, okolicznościowych wystaw, oraz warsztatów i pracowni twórców ludowych. Zachowane sprawozdania szkolne wskazują, iż formę wycieczki w swojej pracy dydaktyczno-wychowawczej stosował m.in. nauczyciel gimnazjum im. Stanisława Staszica w Lublinie. Do wydarzeń odnotowanych przez władze szkolne należy zwiedzanie ekspozycji tej rangi, co Wystawa ruchoma dzieł sztuki zorganizowana przez Departament Kultury i Sztuki Ministerstwa WRioP w Lublinie (1932); Wystawa obrazów i drzeworytów Aleksandra Laszenki ${ }^{45}$ (1934); Wystawa Nowej Sztuki zorganizowana przez Ministerstwo WRioP w Lublinie (1935) ${ }^{46}$. Wycieczka była popularną formą zajęć również w elitarnym gimnazjum ss. urszulanek im. Unii Lubelskiej, gdzie ich

45 Aleksander Laszenko (1883-1944) - polski artysta malarz, podróżnik, współzałożyciel Zrzeszenia Kujawskich Artystów Plastyków. W latach 1901-1904 studiował malarstwo w Petersburskiej Akademii Sztuk Pięknych. W 1904 r. ukończył Konstantynowską Szkołę Artylerii w Petersburgu. 12 lat później otrzymał stopień pułkownika. Jako jeden z niewielu polskich malarzy zajmował się niemal wyłącznie tematyką egzotyczną. Owocem jego podróży do Afryki i na Bliski Wschód były obrazy przedstawiające sceny z życia tubylców, egzotyczne zwierzęta, przyrodę, architekturę starych miast. Oprócz malarstwa zaangażowany był również w archeologię i etnografię. W $1922 \mathrm{r}$. wykonywał rysunki w odkrytym wówczas grobowcu Tutanchamona. Jego prace wielokrotnie pokazywano na wystawach w Polsce (m.in. w Miejskiej Galerii Sztuki w Łodzi) i za granicą. Został pochowany we Włocławku. K. Kotula, Aleksander Laszenko (1883-1944), artysta malarz, w: Zasłużeni dla Włocławka (XIII-XX wiek), red. M. Wojciechowski, Włocławek 1991, s. 115-116.

46 Na podstawie Sprawozdań Dyrekcji Gimnazjum Państwowego im. St. Staszica w Lublinie za rok 1932/1933, 1934/1935. 
stronę naukowo-organizacyjną opracowywały A. Chałubińska i Matka Szczęsna Chruniówna, urszulanka. Z tej samej formy zajęć korzystano w Gimnazjum Państwowym im. Stefana Czarnieckiego w Chełmie i gimnazjum im. B. Głowackiego w Tomaszowie ${ }^{47}$.

Nauka historii sztuki realizowana w ramach rysunku, jako przedmiotu nauczania obejmowała zgodnie z zaleceniami programowymi głównie zagadnienia odnoszące się do polskiej sztuki rodzimej. Powszechnie stosowaną metodą na tego typu lekcjach, była praca referatowo-dyskusyjna, ilustrowana pokazem reprodukcji lub tak zwanymi „obrazami świetlnymi”. Do tematów często omawianych należały: sztuka starożytna; style polskiej sztuki nowożytnej; piękno i kultura miast polskich - w tym Wilna, Krakowa, Lwowa i Warszawy; twórczość artystów polskich np:: Grottgera, Matejki, Wyspiańskiego oraz sztuka ludowa wybranych regionów Polski ${ }^{48}$.

Jedną z szerzej stosowanych prób usprawnienia procesu nauczania była metoda korelacji. W szkołach ogólnokształcących na lekcjach rysunków wykorzystywano wiedzę uczniów nabytą na innych przedmiotach objętych programem nauczania, lub pogłębiano, bądź uzupełniano wiadomości z innych dziedzin; zajęć praktycznych, przyrody, geografii, języka polskiego itp. Głównie jednak przygotowywano uczniów do posługiwania się rysunkiem w nauce innych przedmiotów.

Nauka rysunku, której zasadniczą treścią było tworzenie form na płaszczyźnie, wiązała się ściśle z zajęciami praktycznymi, których celem było budowanie form przestrzennych. Często podkreślano, że zajęcia praktyczne powinny wykorzystywać wyniki obserwacji prowadzone w ramach nauki rysunku. Ze swojej strony zajęcia praktyczne miały przyczyniać się do rozwoju spostrzegawczości i uzupełniać kształcenie wyobraźni przestrzennej przy wykonywaniu zabawek, sprzętów i różnorodnych przyborów. W 1925 r. w Paryżu, na obradach Międzynarodowego Kongresu Rysunku ${ }^{49}$, analizowano związek rysunku z robotami ręcznymi, zaznaczając wielką łączność między tymi umiejętnościami jako wza-

47 B. Wierzchowska-Konera, Szkolnictwo średnie, s. 315.

48 „Ogniwo”, Związek Nauczycielstwa Polskiego. Sekcja Szkolnictwa Średniego, Warszawa 1931, nr 3.

49 Międzynarodowe Kongresy Nauczania Rysunku i Sztuki Stosowanej 1900-1937, Warszawa 1938, s. 18. 
jemnie się wspierającymi i dopełniającymi. Postulowano, by dla osiągnięcia dobrych wyników obydwa przedmioty powierzyć dobrze przygotowanemu artystycznie i technicznie nauczycielowi, co też znalazło odbicie w szkołach lubelskich prowadząc niekiedy do ostrych konfliktów między nauczycielami tych przedmiotów ${ }^{50}$.

Drugim przedmiotem pozostającym w ścisłym związku z nauką rysunku była przyroda. Korelacja rysunku z przyrodą polegała między innymi na tym, że przedmioty te opierały się na obserwacji otaczającej rzeczywistości. Ćwiczenia w obu zakresach miały się zatem uzupełniać, przy czym przyroda miała wnosić w naukę rysunku wiadomości o budowie roślin, zwierząt i człowieka. W 1929 r. na łamach „Dziennika Urzędowego Kuratorium Okręgu Szkolnego Lubelskiego" ukazał się artykuł jednego z nauczycieli szkół lubelskich, w którym pisał on: „Rysunek w nauczaniu przyrodoznawstwa jest dziś tak powszechnym środkiem pomocniczym, że trudno sobie wyobrazić lekcję bez kredek, ołówka czy farbek" ${ }^{\prime 1}$. Często praca domowa uczniów polegała na wykonaniu rysunku motywu roślinnego, schematu biologicznego bądź tablicy poglądowej, czego przykładem są archiwalne prace rysunkowe wykonane przez uczennice Gimnazjum Unii Lubelskiej w Lublinie.

Sprawność rysunkowa uczniów wykorzystywana była w nauce geografii podczas kreślenia orientacyjnych planów, map i szkiców okolicy, ilustrowania tematów geograficznych. Rysunek silny związek wykazywał z nauką języka polskiego. Lektury i pogadanki dostarczały wielu tematów do rysunku tzw. ilustracyjnego. Dużą korzyść widziano też we współpracy polonisty z nauczycielem rysunku, który mógł „właściwie objaśnić formalne czynniki obrazu”52.

Korelacja międzyprzedmiotowa szczególnie silnie uwidaczniała się tam, gdzie niezależnie od obowiązującego programu nauczania wykonywano wiele zadań i prac plastycznych wynikających z potrzeb szkoły. Niektóre z nich zostały odnotowane w sprawozdaniach szkolnych np.: w Gimnazjum im. Stefana Batorego w Lublinie grupa rysunkowa pod kierunkiem nauczyciela Karola Westfala wykonała 44 flagi różnych państw; w Gimnazjum Unii

50 A. Hodbod, Trudności w realizacji programu naukowego gimnazjum i liceów ogólnokształcących, „Muzeum”, 1937, z. 4.

51 J. Firewicz, Uwagi o stosowaniu, s. 21.

52 H. Policht, Interpretowanie obrazów w nauce szkolnej, Kraków 1936, s. 12. 
Lubelskiej przygotowano wspólnie z nauczycielką scenografię do inscenizacji utworów poetyckich m.in. Lokomotywy Julina Tuwima. W Tomaszowie uczniowie Gimnazjum opracowali stronę plastyczną do "Laleczki z saskiej porcelany” M. Gerson-Dąbrowskiej.

Na zakończenie należy dodać, iż artystyczne działania edukacyjne szkół bardzo często wspomagane były przez inicjatywy lokalnych instytucji i społeczności. Chlubnym przykładem takiego współdziałania był teatr amatorski w Chełmie, którego tradycje sięgały jeszcze okresu zaborów, „kiedy spełniał rolę publicznej trybuny, z której padało słowo polskie w jego najczystszej postaci"53. Wychowawczą stroną pracy teatru było między innymi angażowanie do pełnej współpracy na scenie młodzieży gimnazjalnej. Zorganizowana w zespoły dramatyczne, wystawiała różnego rodzaju sztuki sceniczne ${ }^{54}$. Działalność młodzieży szkolnej szkół średnich w Chełmie integrowała Komisja Międzyszkolna. $\mathrm{Z}$ jej inicjatywy uczniowie z wielkim entuzjazmem wystawili szereg widowisk regionalnych: śląskie, lubelsko-polesko-wołyńskie, kaszubskie, podhalańskie i inne. Barwne kostiumy ludowe wypożyczano w Lublinie ${ }^{55}$. Przejawem życia kulturalnego mieszkańców Chełma były różnego rodzaju ekspozycje. Organizowały je przede wszystkim organizacje społeczne, towarzystwa i instytucje. Miejscem wystaw były głównie pomieszczenia w budynku Gimnazjum S. Czarnieckiego oraz sale na plebaniach chełmskich, rzadziej w świetlicach różnych placówek. Były to wystawy książkowe lub wystawy plastyczne znanych malarzy polskich : Stanisława Błońskiego, grupy warszawskiej - Szańkowskiego, Lisowskiego i Makowskiego, artystów z „Salonu Artystów Malarzy Polskich w Krakowie" i innych ${ }^{56}$.

Streszczenie: Podstawą edukacji plastycznej i zarazem jedną z form wychowania estetycznego uczniów średnich szkół ogólnokształcących w latach międzywojennych była nauka rysunku. Rysunek jako szkolny przedmiot nauczania pełnił doniosłą rolę $\mathrm{w}$ wychowaniu i kształceniu młodzieży, zarówno ze względu na jego praktyczne zastosowanie w życiu, jak i walory wychowawcze przyczyniające się do ubogacania osobo-

53 P. Kiernikowski, Miasto Chetm, s. 235.

54 Tamże, s. 237.

55 Tamże, s. 238.

56 Tamże, s. 268, 269. 
wości i estetyki dnia codziennego. Przedmiot ten ujęty został w programach nauczania szkoły średniej ogólnokształcącej zarówno po odzyskaniu niepodległości w 1918 r., jak i w wyniku reformy szkolnej tzw. jędrzejewiczowskiej w 1932 r. Edukacja plastyczna i wychowanie estetyczne miały miejsce w każdym typie lubelskiej szkoły ogólnokształcącej. Zachowane materiały archiwalne (programy nauczania, sprawozdania szkolne dyrekcji, prace plastyczne z lat 1918-1939 itp.) pozwoliły na rekonstrukcję miejsca i roli rysunku w szkolnictwie średnim na Lubelszczyźnie.

Słowa kluczowe: edukacja plastyczna, Polska 1919-1939, wychowanie estetyczne, szkoła średnia

\section{Bibliografia}

Archiwum L. K., Księga Protokołów Naczelnej Organizacji Młodzieży na terenie Państwowego Gimnazjum im. J. I. Kraszewskiego w Białej Podlaskiej, rok szk.1938/39.

Archiwum Szkolne Liceum Ogólnokształcącego w Kraśniku, Protokoły z posiedzenia Rady Pedagogiczne $z$ dn. 31 sierpnia $1938 \mathrm{r}$.

Dr Jadwiga Młodowska (Wychowawczyni i pracownica społeczna), zebrała i ułożyła B. Bobrowska, Kraków 1935.

Historia wychowania wiek XX, red. J. Miąso, Warszawa 1984.

Hodbod A., Trudności w realizacji programu naukowego gimnazjum i liceów ogólnokształcących, „Muzeum”, 1937, z. 4.

I Sprawozdanie 3-letniego Państwowego Gimnazjum im. E. Plater w Białej Podlaskiej za lata 1919/1920, 1920/1921, 1922/1923, Biała Podlaska 1923.

Janczykowski K., O wyzyskanie Muzeum Regionalnego Ziemi Chełmskiej dla potrzeb szkolnych w związku z nowymi programami, „Dziennik Urzędowy Kuratorium Okręgu Szkolnego Lubelskiego", 1934, nr 2.

Kalinowska-Witek B., Kartka z dziejów oświaty lubelskie. Prywatne Żeńskie Gimnazjum i Liceum Ogólnokształcące Wacławy Arciszowej w Lublinie (1912-1949), Lublin 2012.

Kiernikowski P., Miasto Chełm w okresie międzywojennym (1918-1939), Stowarzyszenie Rocznik Chełmski Wyższa Szkoła Stosunków Międzynarodowych i Komunikacji Społecznej, Chełm 2007.

Kot J., Swojski ornament w szkole średniej, „Kształt i Barwa”, 3 (1923).

Martynowiczówna A. , Rysunek w szkole powszechnej, „Sprawy Szkolne”, 7 (1931).

Międzynarodowe Kongresy Nauczania Rysunku i Sztuki Stosowanej 1900-1937, Warszawa 1938.

Mikulski J., Muzeum w Siedlcach. „Dziennik Urzędowy Kuratorium Okręgu Szkolnego Lubelskiego", 1934, nr 2. 
Policht H., Interpretowanie obrazów w nauce szkolnej, Kraków 1936.

Premisa, Dążenia, programy a rzeczywistość w nauce rysunku, „Roboty Ręczne i Rysunki", 1930, nr 1.

Program Gimnazjum Państwowego. Wydział matematyczno-przyrodniczy, Warszawa 1922.

Program nauki w państwowym liceum ogólnokształcacym z polskim językiem nauczania. Tymczasowy. Rysunki, Warszawa 1937.

Program nauki (tymczasowy) w państwowym gimnazjum ogólnokształcacym z polskim językiem nauczania. Rysunek. Warszawa 1937.

Program nauki w gimnazjach państwowych z polskim językiem nauczania, Warszawa 1934.

Program naukowy szkoły średniej. Projekt wypracowany przez Sekcję Szkolnictwa Średniego, Warszawa 1919.

Projekt. Program nauki w siedmioklasowych publicznych szkołach powszechnych i w trzech niższych klasach gimnazjum państwowego. Rysunek. Warszawa 1929.

Sprawozdanie Dyrekcji Gimnazjum Państwowego im. St. Staszica w Lublinie za rok 1932/1933. 1934/1935.

Sprawozdanie Dyrekcji Gimnazjum Państwowego im. St. Staszica w Lublinie za rok $1934 / 1935$.

Sprawozdanie Dyrekcji Państwowego Gimnazjum Koedukacyjnego w Tomaszowie Lubelskim za rok 1918/19, Tomaszów Lubelski 1919.

Sprawozdanie Gimnazjum Żeńskiego w Puławach za rok 1932/1933, Puławy 1934.

Wierzchowska-Konera B., Szkolnictwo średnie ogólnokształcące w województwie lubelskim w latach 1918-1939, Lublin 1981, rozprawa doktorska napisana pod kierunkiem hab. dr hab. K. Poznańskiego, maszynopis, UMcs - Archiwum.

Woch A., Szkolnictwo średnie ogólnokształcace Lublina w latach 1918-1939, Lublin 2013. Żukowska A. M., Koncepcje edukacji plastycznej i metody ich realizacji w polskiej pedagogice artystycznej, w: Komunikowanie artystyczne, red. M. Stępnik, Lublin 2011. 